\title{
Doping Genético e Eugenia: Diálogos além do esporte
}

\section{El Dopaje Genético y Eugenesia: Diálogos más allá del deporte}

\section{Gene Doping and Eugenia: Dialogues Beyond Sport}

\author{
Fecha de recepción: 3 de marzo de 2016 \\ Fecha de evaluación: 29 de abril de 2016 \\ Fecha de aceptación: 4 de mayo de 2016 \\ Disponible en línea: 24 de mayo de 2016 \\ Tiago Vieira Bomtempo*
}

DOI: http://dx.doi.org/10.18359/rlbi.1816

Cómo citar:

Vieira Bomtempo, T. (2016). El dopaje genético y eugenesia: Diálogos más allá del deporte. Revista Latinoamericana de Bioética, 16(2). 82-101. DOI: http://dx.doi.org/10.18359/rlbi.1816

Artículo de reflexión.

** Pontifícia Universidade Católica de Minas Gerais. Correo institucional: tiago.bomtempo@sga. pucminas.br/tiago.15@bol.com.br. ORCID: http://orcid.org/0000-0002-8877-4152. Belo Horizonte, Brasil. 


\section{Resumo}

A engenharia genética trouxe possibilidades antes inimagináveis, em que há pouco tempo atrás era somente vista em filmes. Da terapia gênica, visando a uma correção ou cura de uma enfermidade, passa-se a possibilidade do melhoramento genético, atualmente vislumbrado no mundo dos esportes com o doping genético. Mas, o doping genético não estaria violando o direito ao patrimônio genético não modificado? Ainda que a intervenção genética não se transmita aos descendentes, haveria um melhoramento genético, que afetaria o genoma do atleta e o diferenciaria dos demais atletas e outros indivíduos, ferindo o princípio da igualdade em detrimento da autonomia privada, podendo-se em falar inicialmente em uma relação de dominação, ainda que seja em razão de desempenho físico no esporte. Neste sentido, estas inovações, que perpassam o campo da engenharia genética, incutem uma preocupação acerca da manipulação genética nas futuras gerações, ponto de discussão não somente biomédico, mas também bioético e biojurídico. Assim, surge uma inquietação se esses novos avanços podem afetar a dignidade humana diante de uma possível eugenia, devido à projeção de pessoas e a consequente discriminação por determinada identidade genética. Junto a isto, objetiva-se neste artigo investigar se a dopagem genética ofenderia o direito ao patrimônio genético não modificado e o direito das futuras gerações, levando a uma nova forma de eugenia, ao não permitir o exercício de iguais liberdades fundamentais. Para tanto, faz-se necessária uma pesquisa com base em autores de bioética e biodireita, além de textos legais nacionais e internacionais que envolvem o tema. Imprescindível à discussão de tais questões, principalmente com a proximidade dos Jogos Olímpicos de Verão no Brasil neste ano de 2016, evento alvo para ocorrer os primeiros casos desse método de dopagem. É neste sentido que se justifica o tema desta pesquisa, para reconhecer a necessidade de trazer o doping genético não só para o meio esportivo, mas junto a uma discussão bioética e jurídica, questionando-se as implicações que tal prática possa trazer para a humanidade.

Palavras-chave: Doping genético, direito ao patrimônio genético não modificado, direito das futuras gerações, eugeniae.

\section{Resumen}

La ingeniería genética trajo posibilidades antes inimaginables, en la que no hace mucho tiempo era visto sólo en las películas. De la terapia génica, dirigida hacia una corrección o cura de una enfermedad, pasa a la posibilidad del mejoramiento genético, actualmente vislumbrado en el mundo del deporte con el doping genético. ¿Pero, el doping genético no estaría violando el derecho al patrimonio genético no modificado? Aunque la intervención genética no se transmita a los descendentes, habría un mejoramiento genético, que afectaría el genoma del atleta y lo diferenciaría de los demás atletas y otros individuos, hiriendo el principio de igualdad en detrimento de la autonomía privada, pudiéndose estar hablando inicialmente de una relación de dominación, aunque sea en razón al rendimiento físico en el deporte. En este sentido, estas innovaciones que atraviesan el campo de la ingeniería genética, infunden una preocupación acerca de la manipulación genética en las generaciones futuras, punto de discusión no sólo biomédica, sino también bioético y biojurídico. Así, surge una preocupación si estos nuevos avances pueden afectar a la dignidad humana delante de una posible eugenesia, debido a la proyección de personas y la consecuente discriminación por determinada identidad genética. Junto a esto, el objetivo de este artículo es investigar si el dopaje genético ofendería el derecho al patrimonio genético no modificado y los derechos de las generaciones futuras, dando lugar a una nueva forma de eugenesia, al no permitir el ejercicio igualitario de las libertades fundamentales. Por lo tanto, se hace necesaria una investigación basada en los autores de la bioética y el bioderecho, así como también los textos legales nacionales e internacionales que involucran el tema. Es indispensable la discusión de estas cuestiones, sobre todo con la proximidad de los Juegos Olímpicos de Verano en Brasil en este año 2016, evento propicio para que se produzcan los primeros casos de este método de dopaje. Es en este sentido que se justifica el tema de esta investigación, para reconocer la necesidad de traer el doping genético no sólo para el campo de los deportes, sino también a un debate bioético y jurídico, cuestionando las consecuencias que esta práctica puede llevar a la humanidad.

Palabras claves: Doping genético, derecho al patrimonio genético no modificado, derecho de las generaciones futuras, eugenesia. 


\begin{abstract}
Genetic engineering has brought possibilities before unimaginable, in which not long ago was only seen in movies. Of gene therapy, aiming at a correction or cure a disease, pass the possibility of genetic improvement, currently glimpsed in the sports world with gene doping. But, gene doping would not be violating the right to genetic patrimony unmodified? Though the genetic intervention is not transmitted on to offspring, there would be a genetic enhancement, which would affect the genome of the athlete and differentiate from other athletes and other individuals, injuring the principle of equality to the detriment of private autonomy, It may be to speak initially a relationship of domination, although it is because of physical performance in sports. In this sense, these innovations that permeate the field of genetic engineering, instil a concern about genetic manipulation in future generations, discussion point not only biomedical, but also bioethical and biojuridical. Thus, there arises a concern if these new advances can affect the human dignity in the face of a possible eugenics, due to the projection of people and the consequent discrimination by determined genetic identity. Along with this, the objective of this article is investigate whether gene doping would offend the right to genetic patrimony not modified and the rights of future generations, leading to a new form of eugenics, by not permitting the exercise of equal fundamentals liberties. To this end, research is needed on the basis of authors of bioethics and biolawin addition to national and international legal texts that involve the theme. Indispensable discussion of such questions, especially with the proximity of the Summer Olympic Games in Brazil this year 2016 target event to occur the first cases of this doping method. It is in this sense that justifies the theme of this research, to recognize the need to bring gene doping not only for the sports area, but with a bioethical and legal discussion, questioning the implications that this practice can bring to humanity.
\end{abstract}

Keywords: Gene doping, right to genetic patrimony unmodified, rights of future generations, eugenics.

\section{Introdução}

O provável emprego do doping genético só tornou-se hoje uma realidade a partir do sequenciamento do genoma humano, com o Projeto Genoma Humano. Desde então, com a identificação de cada gene e suas respectivas proteínas responsáveis por determinada atividade no corpo humano, entre elas, a eritropoetina (resistência), bloqueadores de miostatina (crescimento da musculatura), IGF-1 e GH (força), leptina (perda de peso), VEGF (energia), endorfinas e encefalinas (analgésicos) e PPAR- (resistência) (Artioli, Hirata \& Lancha, 2007), a dopagem com o recurso da biologia molecular e da genética passaram a ser alvo dos órgãos antidoping, como a WADA (World Anti-Doping Agency).

Além do risco de não garantir o jogo limpo e o espírito esportivo, o doping genético mostra-se assim como mais uma forma de manipulação genética, colocando em risco a integridade genética do indivíduo ao intervir no genoma humano, como defende Coelho:

O genoma é um indicativo, não somos nosso genoma e, por isso, é cada vez mais urgente compreender melhor a antropologia fundamental e em particular na relação entre genoma humano e pessoa humana. De fato, com base na redescoberta do signi- 
ficado pessoal do genoma humano, consegue-se compreender até mesmo como é moralmente incorreta qualquer intervenção que não procure integrar o ser pessoal, por meio da manipulação de sua natureza biológica. Uma ação lícita é aquela que respeita a verdade e a dignidade do homem em sua integridade genética e identidade de pessoa, e uma ação ilícita é a que manipula o homem e $\mathrm{o}$ aliena de si mesmo [...]. (Coelho, 2012, p.179).

Ademais, se desde o Projeto Genoma Humano a identidade genética da pessoa já estava em risco, sobretudo nas relações laborais, na contratação de seguros e nas relações familiares, o doping genético aparece como nova técnica que possa causar discriminação genética, a princípio no âmbito esportivo, mas que tende a se estender na sociedade como um todo. Afinal, ser mais forte ou mais rápido não traz benefícios só no esporte, mas em outras situações ou relações que o atleta tenha ou possa vir a ter.

Não obstante, torna-se ainda mais preocupante a questão do eugenismo, uma vez que, além da reprodução assistida, o doping genético também pode ser uma "porta de entrada" para a criação de um ser humano melhorado não somente dotado de características atléticas, mas da seleção de capacidades físicas, estéticas, biológicas e intelectuais que possam dividir a raça humana entre os melhorados geneticamente ou transgênicos e os não-transgênicos. Por conseguinte, poderia ocorrer uma higienização da- queles que não atenderiam os padrões de "perfeição" (Junges, 1999).

Vislumbra-se, assim, o uso do doping genético como meio de instrumentalização do ser humano, subjugado a um objeto para interesses que se desviam da dignidade humana, pois, "expor o corpo e o sujeito até o limite desvela a vitrine consumista que reduz quase tudo e a todos a objeto de circulação" (Fachin, 2004, p. 189). Conforme Barbas (2005, p.320), "a engenharia genética de melhoramento colide com o princípio da não instrumentalização do ser humano, princípio este que faz com que cada homem seja sempre considerado um fim em si mesmo, e nunca um meio para atingir determinado fim".

Urge-se, portanto, por uma discussão que trate de forma mais aprofundada os contornos que envolvem o doping genético, sobretudo, no perigo de se violar a dignidade da pessoa humana, reduzindo o próprio indivíduo a instrumento da técnica e de interesses de mercado, em uma escolha sem volta antes de uma conscientização dos riscos que estão em jogo, sob pena de comprometer as gerações atuais e futuras.

Para tanto, propõe-se discutir inicialmente o doping genético no que tange ao direito ao patrimônio genético não modificado, abordando em seguida suas implicações no direito das gerações futuras, e, por fim, se a dopagem genética pode ser compreendida como uma nova forma de eugenia. 


\section{Direito ao patrimônio genético não modificado e doping genético}

No âmbito internacional, o direito ao patrimônio genético não modificado foi cunhado pela Declaração Universal do Genoma Humano e dos Direitos Humanos da UNESCO em 1997, ratificada na atual, de 1999, ao dispor logo no artigo $1^{\circ}$ que "o genoma humano constitui a base da unidade fundamental de todos os membros da família humana bem como de sua inerente dignidade e diversidade. Num sentido simbólico, é o patrimônio da humanidade." (Organização das Nações Unidas para a Educação, Ciência e Cultura [UNESCO], 1999).

Cumpre esclarecer que a expressão "patrimônio da humanidade" dada ao genoma humano não se refere a um sentido pecuniário ou de propriedade, como um direito patrimonial, mas no sentido de preservação da espécie humana, sendo a própria humanidade titular desse direito (Gomes \& Sordi, 2001).

Assim, o direito ao patrimônio genético não modificado inclui a proteção do direito à vida, "no sentido de permanecer existindo, com os consectários que lhe são peculiares: direito a sua identidade - implica a integridade do seu genoma, dignidade, intimidade, igualdade, não discriminação, liberdade etc." (Gomes \& Sordi, 2001, p.172).

No Brasil, o direito ao patrimônio genético não modificado está positivado no art. 225, $\S 1^{\circ}$, inc. II da Constituição da República de 1988:
Art. 225. Todos têm direito ao meio ambiente ecologicamente equilibrado, bem de uso comum do povo e essencial à sadia qualidade de vida, impondo-se ao Poder Público e à coletividade o dever de defendê-lo e preservá-lo para as presentes e futuras gerações.

$\S 1^{\circ}$-Para assegurar a efetividade desse direito, incumbe ao Poder Público:

[...] II-preservar a diversidade e a integridade do patrimônio genético do País e fiscalizar as entidades dedicadas à pesquisa e manipulação de material genético; [...] (Brasil, 1988).

Como observado por Diedrich (2001) o legislador constituinte não foi feliz na elaboração desse dispositivo constitucional, pois, a proteção do genoma humano surge da preservação do meio ambiente, tratando a integridade genética do homem de forma indireta. Ainda que o direito ao patrimônio genético humano não modificado esteja garantido com base na dignidade da pessoa humana e outros direitos fundamentais, mesmo após 15 anos da edição da Declaração Universal do Genoma Humano e dos Direitos Humanos da UNESCO, não houve modificação no texto constitucional brasileiro que tratasse explicitamente a proteção do genoma humano.

Ademais, a Lei de Biossegurança, Lei n.11.105/2005, no artigo $6^{\circ}$, inciso III $^{1}$,

1 "Art. 6o Fica proibido: III - engenharia genética em célula germinal humana, zigoto humano e embrião humano" (Brasil, 2005). 
protege o patrimônio genético, porém, somente em linha celular germinal. Em um primeiro momento, entendeu-se que a partir de uma interpretação literal deste artigo infraconstitucional, poderia se inferir que a engenharia genética em linha celular somática poderia ser permitida, o que, por conseguinte, sob o ponto de vista legal, o doping genético não seria ilegal no Brasil (Mello \& Bomtempo, 2013).

Entretanto, uma vez que não se está tratando de uma terapêutica, como a terapia gênica, mesmo na intervenção em células somáticas pode-se entender que o doping genético é vedado no Brasil, pois é uma técnica de melhoramento, a qual não se sabe ainda se os efeitos em células somáticas podem atingir células germinativas, como afirma Casabona:

[...] A preocupação sobre essa possível terapia futura na linha germinal ou sobre as intervenções de aperfeiçoamento reside, ademais, em que as modificações genéticas se transmitiriam às sucessivas gerações da estirpe tratada. Tal inquietação não se coloca com a intervenção do gene-terapêutica ou perfectiva na linhagem somática, pois, em princípio as modificações genéticas somente deveriam afetar ao paciente tratado, por não ter que envolver suas células reprodutivas; não obstante, não se conhecem ainda de modo suficiente outros efeitos colaterais, como poderiam ser mutações genéticas não previstas, incluído as das células germinativas. Daí que se pondere a terapia gênica com certa prudência e se chame a atenção sobre a cautela que deveria imperar sobre qualquer atuação deste tipo. (Casabona, 2002, p.106) $)^{2}$.

E, isto não afasta a ideia de violação ao patrimônio genético não modificado, que antes de remeter-se à espécie humana, remete-se ao genoma de cada ser humano, isto é, o atleta ao fazer uso do doping genético, mesmo ao nível de células somáticas, modifica o seu genoma, o que, consequentemente, devido aos fins de aprimoramento, infringe o direito ao patrimônio genético não modificado.

Urge-se, portanto, pelo respeito ao princípio biojurídico da precaução, de forma que não se incorra no risco do doping genético violar o direito ao patrimônio genético não modificado. Conforme Ascensão:

2 La preocupación sobre esa futurible terapia en la línea germinal o sobre las intervenciones perfectivas radica, además, en que las modificaciones genéticas se transmitirían a las sucesivas generaciones de la estirpe tratada. Tal inquietud no se plantea con la intervención gênica - terapêutica o perfectiva - en la línea somática, pues, en principio las modificaciones genéticas sólo deberían afectar al paciente tratado, al no tener que implicar a sus células de la reproducción; no obstante, no se conocen todavía de modo suficiente otros efectos colaterales, como podrían ser mutaciones genéticas imprevistas, incluidas las de las células germinales. De ahí que se valore la terapia génica con cierta prudencia, y que se llame la atención sobre la cautela que debería presidir cualquier actuación de este tipo. 
Isto levou a desenvolver um princípio da precaução, dirigido a controlar a evolução para evitar que se desemboque em consequências que sejam já irreparáveis. É proclamado em todos os sectores de risco. E tem sido referido expressamente à biotecnologia, sempre que o ecossistema ou a saúde ou integridades humanas estejam em risco. (Ascensão, 2005, p.26).

Ressalta-se que não se deve levar em conta somente na segurança da técnica e nos efeitos na saúde humana e na descendência, mas na própria questão instrumentalizadora do uso da dopagem genética em modificar o genoma humano com fins de melhoramento e de dominação humana (Sgreccia, 1996).

Menciona-se o princípio da responsabilidade amplamente discutido por Hans Jonas (2006), a fim de se evitar qualquer intervenção no genoma humano que possa degradar a integridade futura da "imagem e semelhança" humana. "Tratase de assumir a responsabilidade pelo futuro do homem." (Jonas, 2006, p.353).

E esta responsabilidade trata-se de um princípio biojurídico, o qual infere em responder por eventuais danos que possam ocorrer pelas técnicas de manipulação genética, como o doping genético.

Fala-se do dano gênico, do dano genômico e do dano poligênico, em razão da lesão ao gene, do genoma e da extensão destes danos à descendência, respectivamente (Andrade, 2003).
Essa nova manifestação de dano foi concebida no artigo $8^{\circ}$ da Declaração Universal do Genoma Humano e dos Direitos Humanos da UNESCO, ao dispor que "cada indivíduo terá direito, conforme a legislação nacional ou internacional, à justa indenização por qualquer dano sofrido resultante, direta ou indiretamente, de intervenção sobre seu genoma." (UNESCO, 1999).

Insurge-se que este dano poderia ser não somente individual, mas também coletivo, na medida em que não se sabe quais danos e como estes poderiam se estender para toda a descendência, afetando as futuras gerações e causando um empobrecimento ou uma erosão da diversidade genética humana (Barbas, 2005).

A seu turno, pretende-se a seguir justamente abordar os desafios que o doping genético possa enfrentar diante do direito das futuras gerações.

\section{Impacto da dopagem genética nas futuras gerações}

O doping genético traz a polêmica de comprometer as gerações futuras, sobretudo, a partir de seu emprego nas células germinativas.

Neste contexto, vários documentos internacionais e nacionais se manifestaram a respeito de se proibir qualquer forma de manipulação genética de aperfeiçoamento, visando à proteção das futuras gerações. 
No âmbito internacional menciona-se a Declaração sobre as Responsabilidades das Gerações Presentes em Relação às Gerações Futuras da UNESCO ${ }^{3}$ no ano de 1997, bem como a Convenção dos Direitos do Homem e da Biomedicina (Oviedo, Espanha, 1997), que aduz em seu artigo 13 que "uma intervenção que tenha por objeto modificar o genoma humano não pode ser levada a efeito senão por razões preventivas, de diagnóstico ou terapêuticas e somente se não tiver por finalidade introduzir uma modificação no genoma da descendência" (Conselho da Europa, 1997). Além disso, a Convenção não permite no artigo 14 "a utilização de técnicas de procriação medicamente assistida para escolher o sexo da criança a nascer, salvo para evitar graves doenças hereditárias ligadas ao sexo" (Conselho da Europa, 1997).

No Brasil, a Constituição da República de 1988 protege no art. 220 o meio ambiente ecologicamente equilibrado para as presentes e futuras gerações, inclusive a preservação da diversidade e integridade do patrimônio genético do País (Brasil, 1988).

Objetivando regulamentar o referido dispositivo constitucional, a atual Lei

\footnotetext{
"Artigo 6 - Genoma humano e biodiversidade. O genoma humano, com pleno respeito à dignidade da pessoa humana e aos direitos humanos, deve ser protegido, e a biodiversidade salvaguardada. O progresso científico e tecnológico não deve, de forma alguma, prejudicar ou comprometer a preservação da espécie humana e de outras espécies" (unesco, 1997).
}

$n^{\circ} .11 .105$ de 2005, que revogou a Lei n. 8.974 de 1995, tratou de, como citado, de proibir no art. $6^{\circ}$, inc. III, a engenharia genética em célula germinal humana, zigoto humano e embrião humano, bem como tipifica como crime esta prática em seu art.25, com a pena de reclusão de 1 a 4 anos, além de multa (Brasil, 2005). Observa-se, assim, a preocupação do legislador em garantir o direito das futuras gerações a um patrimônio genético não modificado ao coibir a manipulação genética em linhagem germinal.

O CFM também buscou proteger as gerações futuras em seu código de ética, que, ainda que não tenha força de lei, pois não foi criado pelo devido processo legal, possui caráter normativo para a classe médica (Bomtempo, 2013). De acordo com o capítulo I, XXV e capítulo $3^{\circ}$, art. 15 e art. 16 do Código de Ética Médica (CEM):

XXV-Na aplicação dos conhecimentos criados pelas novas tecnologias, considerando-se suas repercussões tanto nas gerações presentes quanto nas futuras, o médico zelará para que as pessoas não sejam discriminadas por nenhuma razão vinculada à herança genética, protegendo-as em sua dignidade, identidade e integridade. [...]

Art. 15. Descumprir legislação específica nos casos de transplantes de órgãos ou de tecidos, esterilização, fecundação artificial, abortamento, manipulação ou terapia genética. 
[...] \& $2^{\circ} \mathrm{O}$ médico não deve realizar a procriação medicamente assistida com nenhum dos seguintes objetivos:

I-criar seres humanos geneticamente modificados;

II - criar embriões para investigação; III - criar embriões com finalidades de escolha de sexo, eugenia ou para originar híbridos ou quimeras. [...]

Art. 16. Intervir sobre o genoma humano com vista à sua modificação, exceto na terapia gênica, excluindo-se qualquer ação em células germinativas que resulte na modificação genética da descendência. (Conselho Federal de Medicina [CFM], 2009).

Com base no art. 16 do CEM, do direito à vida, da dignidade da pessoa humana e da saúde, a terapia gênica em linha germinal não é proibida no Brasil, desde que seja voltada para o tratamento de doenças.

No Brasil, "a realização desses ensaios clínicos de terapia gênica depende de aprovação prévia por comitês de ética locais e nacionais, como a Comissão Nacional de Ética em Pesquisa (Conep)" (Linden, 2010, p.40).

A terapia gênica atualmente concentra seus estudos de experimentação nos Estados Unidos, Reino Unido, Alemanha, Suíça, França, Austrália, Holanda, Bélgica, Canadá e China (Linden, 2010).

Observa-se, assim, uma tendência mundial nos estudos da terapia gênica que começa a se concretizar em escala comer- cial somente a nível de células somáticas, considerando que um dos receios do uso da terapia gênica germinal seriam as "possíveis anomalias ou má-formações graves que os filhos poderão apresentar" (Casabona, 2007, p.40).

Por outro lado, entende Bostrom que os efeitos negativos da terapia gênica germinal poderiam ser solucionados com outra terapia gênica germinal (Bostrom, 2003).

Acrescenta Barbas (2005) que a alteração significativa de um gene em razão da terapia gênica germinal que viesse a por em risco a diversidade genética seriam necessárias várias centenas de gerações, implicando que, "os efeitos sobre a diversidade genética seriam inferiores ao que se podia pensar." (Barbas, 2005, p.319).

Mas será que o risco valeria a pena? E o consentimento de alguém que não existe no presente para autorizar os improváveis efeitos que a terapia gênica ou mesmo o doping genético poderiam causar, mas que sofrerá suas consequências no futuro? Pondera Jonas que:

[...] Mas o "futuro" não está representando em nenhuma instância; ele não é uma força que possa pesar na balança. Aquilo que não existe não faz nenhum lobby, e os não-nascidos são impotentes. Com isso, os que lhes devem prestar contas não têm por ora nenhuma realidade política diante de si no processo de tomada de decisão; quando aqueles puderem 
reivindicá-la, nós, os responsáveis, não existiremos mais. (Jonas, 2006, p.64).

Ademais, além do doping genético objetivar o aperfeiçoamento genético do atleta, também pode ser transmitido à sua descendência, criando-se superbebês em futuros atletas. Assim, estar-se-ia condicionando os projetos de vida dessas futuras crianças em serem esportistas, ao invés de poderem construir suas próprias histórias, a restringir "especificamente em sua liberdade de escolha de uma vida própria" (Habermas, 2004, p.84).

Neste entendimento, os atletas que fizessem uso da dopagem genética em células germinativas seriam os programadores de seus futuros filhos, retirando a estes seu futuro poder de decisão em ser o que quiserem. Alerta Drumond:

Nenhuma intervenção no organismo humano é inócua, seja ela de natureza clínica ou cirúrgica. No atual estado da arte tecnológica, a manipulação do genoma com vistas a obter um embrião com características diferenciadas em uma ou em outra atividade esportiva, poderá trazer tardiamente consequências não previstas e que podem causar questionamentos de quem foi alvo dessa alteração. A vida humana, para ser exercida de forma integral, deve ser consciente e, portanto, baseada no poder de decisão (autonomia) do ser humano sobre seus próprios atos, atuais ou futuros. (Drumond, 2011, p.417).
Tal procedimento implicaria na instrumentalização dos futuros filhos dos atletas, que, a partir de um desejo egoístico, de alcançar os melhores resultados com uma prática proibida, tornaria sua descendência objeto de suas escolhas, incorrendo em um paternalismo sui generis.

Sobretudo, a criação de futuros bebês atletas poderia gerar uma fonte de lucro e a perpetuação de esportistas na descendência, tornando-se instrumentos de interesses econômicos, o que se atentaria contra a dignidade humana. Afinal, qual pai ou mãe que não queria ter um filho que ganhasse o que Floyd Mayweather Jr. ganha no boxe ou o que Maria Sharapova ganha no tênis ${ }^{4}$ ?

\section{Conforme Ascensão:}

[...] Abrir neste momento a possibilidade de modificação do genoma humano com efeitos sobre as gerações futuras seria transformar a genômica em objeto de lucro, mais do que já está, sem qualquer instrumento ou possibilidade séria de controlo. Este é um dos grandes riscos que paira atualmente sobre a dignidade humana. (Ascensão, 2005, p.46)

$4 \quad$ De acordo com a Revista Forbes, o boxeador Floyd Mayweather Jr. é o atleta mais bem pago no mundo com o ganho de US\$300 milhões de dólares, enquanto a tenista Maria Sharapova é a atleta mais bem paga no mundo com o ganho de US\$29,7 milhões de dólares no ano de 2015 (Badenhausen, 2015). 
Menciona-se ainda ao fato de que com a programação de atletas criados geneticamente poderia se conduzir à abertura de seleção de características de embriões, na produção de seres com características ditas "perfeitas", somente acessível aos que tivessem poder econômico. Configuraria segregação dos melhorados e dos não melhorados geneticamente, o que é vedado pelo artigo 11 da Declaração sobre as Responsabilidades das Gerações Presentes em Relação às Gerações Futuras da UNESCO ${ }^{5}$ de 1997.

Em posição contrária, defende Bostrom (2003) que este tipo de problema poderia ser solucionado com políticas sociais, ampliando o acesso à tecnologia, que, subsidiada ou fornecida gratuitamente, fosse dada acesso aos pais sem recursos financeiros, chegando a ser disponível a todos, com base na justiça social e na solidariedade.

Se nem o acesso básico à saúde a maioria da população mundial tem acesso, o que dizer de técnicas de melhoramento genético? Ademais, e a autonomia do futuro ser? Com esse posicionamento de Bostrom (2003) não é possível resolver esta questão. Assim, pactua-se ao entendimento de Habermas (2004), em que somente cabe a intervenção em células germinativas para se evitar males extremos e altamente generalizados, que

5 "Artigo 11 -Não discriminação. As gerações presentes devem evitar tomar qualquer ação ou medida que tenha efeito que gere ou perpetue qualquer forma de discriminação para as gerações futuras." (UNESCO, 1997). seriam justificados desde que a doença grave fosse prognosticada com segurança e de forma indubitável, além da certeza de que a terapia gênica não trouxesse risco à saúde da pessoa, em respeito aos princípios bioéticos e biojurídicos.

Portanto, o direito às futuras gerações deve ser preservado em respeito ao direito a um patrimônio genético não modificado, não cabendo, pois, qualquer intervenção com o objetivo de melhoramento, como o doping genético, a fim de se evitar discriminação genética e uma futura eugenia, o que se propõe discutir a seguir.

\section{Doping genético: a caminho de uma nova forma de eugenia?}

A eugenia está quase sempre associada às decisões políticas de Estado, porém, com os avanços da engenharia genética e suas técnicas de melhoramento, como o doping genético, hoje já se discute a chamada eugenia liberal, a partir de decisões fundadas na liberdade do indivíduo.

O termo eugenia provém do grego, que significa: eu=bom e genus=nascimento, ou seja, significa bom nascimento (Carvalho, 2011). Foi cunhado pelo inglês Francis Galton, primo de Charles Darwin (Westman, 2006).

A eugenia, no que tange às intervenções de ordem genética, pode ser traduzida como a intenção de criar o chamado "pool genético da humanidade com o fim de potencializar a transmissão dos genes que 
recebem a classificação de "bons" para alcançar melhorias genéticas ao mesmo tempo em que se tenta suprimir, mudar ou anular a expressão e transferência daqueles" (Cancino, 2007, p.268) que não são "bons".

Vislumbram-se, assim, novas possibilidades de eugenia aplicadas no campo da genética, também chamada de neoeugenesia ou eugenética (Coelho, 2012). Neste contexto, aparecem duas formas de eugenia, a que "pode ser negativa, se voltada para a cura e prevenção de doenças e malformações genéticas, ou positiva, se buscar a melhoria das competências humanas, como inteligência, memória, criatividade, traços do caráter ou outros caracteres psicofísicos" (Diniz, 2006, p.484).

No âmbito da eugenia negativa, a qualé ética e juridicamente aceita encontra-se a terapia gênica, a qual "deve procurar superar a moléstia, não podendo superar as características hereditárias não patológicas, e muito menos pretender a eugenia, em busca de um ser humano perfeito" (Diniz, 2006, p.470). Objetivando os fins de tratamento e cura de doenças genéticas, a terapia gênica seria lícita, mesmo como eugenia negativa, pois, como também aponta Carvalho (2011, p. 641) "O eugenismo negativo visa à prevenção de doenças mediante a correção dos genes. O eugenismo positivo é o que atua na melhoria psicofísica do ser humano".

Seguindo este entendimento, pode se observar a atuação da eugenia positiva na performance dos atletas com o aperfeiçoamento do corpo numa nova forma do agir eugênico, como explicam Silva e Goellner:

Com isso, o híbrido "homem-máquina" não é o fim do corpo, mas a forma excelente de sua afirmação em uma sociedade em que a biotecnologia articula as novas formas do agir eugênico, em que o aperfeiçoamento é uma constante e a ação performática é uma condição. [...]. (Silva \& Goellner, 2007, p.84).

Sendo assim, com o fito de melhorar o desempenho físico nas competições esportivas, o doping genético não poderia ser enquadrado como uma forma de eugenia positiva? $\mathrm{Na}$ medida em que no atleta saudável é introduzido em seu genoma um gene responsável pelo aumento da resistência física, da massa muscular e/ou de energia com o emprego da engenharia genética, este melhoramento, pode-se entender, seria uma forma de eugenia positiva (Mello $\&$ Bomtempo, 2013).

Por conseguinte, "deverá ser colocado limites à eugenia, quer dizer, à prática médica que procura a criação e evolução de uma raça superior (perfect people), o que se consegue modificando os genes (seja do crescimento, da cor da pele ou das dimensões corporais, etc.)" (Rospigliosi, 2001, p. 150) ${ }^{6}$.

$6 \quad$ "Se deberá poner límites a la eugenesia, es decir, a la práctica médica que busca la creación y evolución de una raza superior 
Em posicionamento contrário, Ascensão (2005) advoga a tese da "igualdade da inveja", que, calcado na concepção utilitarista, entende que "tudo o que for benéfico para alguns deve deixar-nos contentes. Como chegar aos outros, é outra questão. [...]." (Ascensão, 2005, p.38).

Todavia, não se pode pactuar com tal entendimento, porque, do contrário, "a engenharia genética de melhoramento pode conduzir à "fabricação" intencional de duas espécies de seres humanos. As modificações genéticas que viessem provocar distinções raciais, étnicas ou de classe e, por maioria de razão, qualquer ideia de criar uma nova raça ofenderia o princípio da igualdade da pessoa" (Barbas, 2005, p.321).

Ademais, como defende Melo (2011), essa estigmatização poderia causar o empobrecimento cultural da sociedade, com o agrupamento das pessoas conforme a sua constituição biogenética, deixando de lado o entendimento hoje dominante nas sociedades ocidentais de pessoas com diferentes habilidades.

Neste contexto, a sociedade estaria não só dividida em ricos e pobres, isto é, a discriminação econômica passaria a ser também biogenética, tendo acesso ao melhoramento genético somente as pessoas com capacidade econômica

(perfect people), lo que se logra modificando los genes (sea del crecimiento, del color de la piel o de las dimensiones corporales, etc.)." suficiente para arcar com os custos da técnica. Estar-se-ia, assim, diante de duas espécies humanas.

Além disso, a manipulação genética pode ocasionar a programação de o futuro ser, prejudicando a sua futura autonomia e autocompreensão moral (Habermas, 2004), ao ser fruto de objeto de escolhas egoísticas dos pais ou mesmo do Estado.

Parte-se do fato de que o doping genético em linha germinal, ao afetar a futura descendência do atleta, condicionaria seus filhos a também serem atletas, instrumentalizando-os ao interferir nos seus individuais projetos de vida, ao mesmo tempo em que criaria seres melhorados geneticamente com características superiores às outras pessoas, resultando em eugenia positiva.

Ou pior ainda, poderia o Estado programar as pessoas para garantir a produção e produtividade econômica, gerando indivíduos-objetos conforme suas necessidades, como mineiros com baixa estatura e com grande força muscular para trabalhar nas minas, pilotos insensíveis à altura e às altas velocidades, nadadores esguios, soldados mais resistentes à dor $e$ às emoções, ou pessoas que fossem criadas exclusivamente para trabalharem em serviços burocráticos ou científicos (Rospigliosi, 2001).

Do outro lado, defende Bostrom ao uso da engenharia genética em linhagem germinal, ainda que venha causar desigualdades, em razão dos benefícios que possam ser alcançados: 
Enquanto nós temos hoje vastas desigualdades e consideramos muitas delas como injustas, nós também aceitamos uma ampla gama de desigualdades, porque pensamos que elas são merecidas, têm benefícios sociais, ou são concomitantes inevitáveis de indivíduos livres que fazem suas próprias escolhas e às vezes insensatas sobre como viver suas vidas. Algumas destas justificações também podem ser utilizadas para dispensar algumas desigualdades que poderiam resultar de engenharia de linha germinal. Além disso, o aumento das desigualdades injustas devido à tecnologia não é uma razão suficiente para desencorajar o desenvolvimento e utilização da tecnologia. Devemos também considerar seus benefícios, que incluem não só as externalidades positivas, mas também os valores intrínsecos que residem em bens como o gozo de saúde, uma mente crescente e bem-estar emocional. (Bostrom, 2003, p.17, tradução nossa ${ }^{7}$.

$7 \quad$ While we have vast inequalities today and regard many of these as unfair, we also accept a wide range of inequalities because we think that they are deserved, have social benefits, or are unavoidable concomitants to free individuals making their own and sometimes foolish choices about how to live their lives. Some of these justifications can also be used to exonerate some inequalities that could result from germ-line engineering. Moreover, the increase in unjust inequalities due to technology is not a sufficient reason for discouraging the development and use of the technology. We must also consider its benefits, which include not only positive
Apesar dos benefícios que a engenharia de melhoramento genético possa trazer, bem como a dopagem genética, mesmo com a segurança da técnica, "poderá configurar-se injusta essa linha de investigação (especialmente quando se tratar de financiamento público), enquanto a maioria da população ainda não dispõe das suas mais básicas condições sanitárias satisfeitas" (Drumond, 2011, p. 416).

Em acréscimo, retoma-se a ideia de eugenia liberal proposta por Habermas, a qual "não reconhece um limite entre intervenções terapêuticas e de aperfeiçoamento, mas deixa às preferências individuais dos integrantes do mercado a escolha dos objetivos relativos a intervenções que alteram características" (Habermas, 2004, p. 27).

Desta forma, indaga-se se o doping genético, além de configurar uma eugenia positiva, degradaria a dignidade humana, sendo mais uma forma de instrumentalização do corpo, na medida em que os atletas por interesses de mercado recorreriam a esta forma de dopagem, para garantir vitórias em nome da fama e dinheiro.

Ajustado a esta lógica de mercado, questiona-se esta eugenia liberal, do homem vir a ser o que quiser, podendo fazer uso do melhoramento genético que melhor lhe sirva (Ascensão, 2005).

externalities but also intrinsic values that reside in such goods as the enjoyment of health, a soaring mind, and emotional well-being. 
Neste diapasão, propugna-se que o melhoramento genético humano viria a ter os mesmos objetivos que o melhoramento animal, o qual é definido como "a ciência que estuda as ações da genética dos indivíduos e do ambiente na determinação de suas características de interesse econômico. Essa ciência se divide, basicamente, em duas ações: a seleção e os sistemas de acasalamento" (Ferraz, Eler \& Rezende, 2012, p. 2).

Aplicando-se à realidade do melhoramento animal, seria possível determinar a avaliação genética de cada ser humano melhorado. Segundo Ferraz, Eler e Rezende:

O valor genético dos animais depende da ação dos genes envolvidos na determinação das características, do número de informações a respeito dos animais avaliados (quanto maior este número, melhor a estimativa do valor genético), do parentesco entre os animais avaliados e as fontes de informação (quanto mais próximo o parentesco, maior a ênfase que a informação deve ter), além dos chamados efeitos permanentes de ambiente e da precisão com que os efeitos de ambiente são identificados. (Ferraz et al., 2012, p. 4).

Por conseguinte, quanto mais genes adicionados e expressos no fenótipo do atleta melhorado, alcançando melhores resultados e transmitidos à descendência, maior valor genético este esportista teria. Desta forma, as pessoas passariam a deixar de ter dignidade e passariam a ter valor genético, podendo ser traduzido em valor econômico, contrariando a concepção kantiana de dignidade: "quando uma coisa está acima de todo o preço, e, portanto, não permite equivalente, então tem ela dignidade" (Kant, 1993, p. 77).

A reforçar esta ordem de ideias, Habermas (2004, p. 47) sustenta que "a dignidade humana marca, antes, aquela "intangibilidade" que só pode ter um significado nas relações interpessoais de reconhecimento recíproco e no relacionamento igualitário entre as pessoas". (Habermas, 2004, p. 47).

Com base neste entendimento, afirma-se que a eugenia positiva neste momento viola a dignidade da pessoa humana, pois as técnicas de melhoramento humano, como o doping genético, não garantirão a igualdade nem perante os outros atletas que não fizerem seu uso e nem diante das pessoas que não forem melhoradas geneticamente, além de dar margem à avaliação genética.

De outro modo, Stancioli e Carvalho (2011) argumentam que não se devem proibir as práticas de melhoramento genético, uma vez que esta é uma tendência da evolução humana, devendo-se as tecnologias serem utilizadas para melhorar a qualidade de vida das pessoas, o que já vem sendo realizado com a fusão entre homem e máquina. Assim, o corpo não deve ser visto como dado, mas em constante construção.

Como conciliar então estas duas concepções de dignidade? De um lado 
entendida como igualdade e de outro como autonomia? Conforme Ascensão:

O que nos leva forçosamente a refletir. Há alguma coisa que não está certa na invocação da dignidade da pessoa. Porque se há que serve para tudo, então não serve para nada. Acaba por se transformar numa fórmula vazia. À expressão enfática, a "eminente dignidade da pessoa humana", corresponde cada vez menos um conteúdo definido. (Ascensão, 2013, p. 10).

Sarlet defende que a dignidade humana "acabará alcançando pleno sentido e operacionalidade em face do caso concreto" (Sarlet, 2001, p. 57).

Chamon Júnior aduz que o princípio da dignidade garante "igualmente o direito de conduzirmos nossa vida da maneira que melhor entendemos e desde que de maneira compatível com as esferas de liberdades, com os direitos alheios" (Chamon, 2010, p. 39).

Acrescenta Hammerschmidt (2012) que a dignidade humana significa promover os projetos de autorrealização de cada pessoa, sem que prejudique aos outros, não sendo a pessoa um meio ou um instrumento causando-lhe prejuízos.

Unindo-se esses três conceitos de dignidade, permite-se compreender que o doping genético como eugenia positiva somente seria permitido na medida em que fosse exercício da autonomia do atleta e não causasse violação à igualdade perante os outros atletas e/ou em outras relações no seio da sociedade. É o que se concebe a partir de Habermas:

[...] Contudo, esse programa só é compatível com os fundamentos do liberalismo político, se as intervenções eugênicas positivas em pessoas tratadas geneticamente não limitarem nem as possibilidades de uma conduta de vida autônoma, nem as condições de um trato igualitário com outras pessoas. (Habermas, 2004, p. 68).

Portanto, em respeito aos princípios biojurídicos da autonomia privada, dignidade, precaução e responsabilidade (Sá \& Naves, 2011), ainda não é possível permitir o doping genético, visto como forma de eugenia positiva, por objetivar o melhoramento humano e por em risco o futuro da humanidade, "convidando-nos a cometer todos os devaneios, num genuíno eros científico que nos poderá levar à incapacidade de domínio dos próprios produtos do génio humano, abrindo de par em par a Caixa de Pandora da nossa existência[...], com todos os riscos inerentes a essa decisão." (Garcia \& Lemos, 2005, p. 38).

Ante o exposto, urge-se por uma discussão mais aberta acerca dos entraves que envolvem o doping genético, de forma que toda a sociedade, no contexto do Estado Democrático de Direito, possa, por exercício do discurso e em respeito às iguais liberdades fundamentais debater esta tão polêmica temática. Afinal, aproximam-se no Brasil os Jogos Olímpicos de 2016 e receia-se o apareci- 
mento desse novo método de dopagem, carecendo veemente um diálogo mais aberto dentro da sociedade brasileira e da comunidade internacional.

\section{Conclusões}

Por meio deste artigo verificou-se que a engenharia genética de melhoramento aplicada ao esporte, sob a roupagem do doping genético é uma realidade, porém, ainda sem comprovações.

O uso do corpo pode fulminar a dignidade humana para fins meramente egoísticos, como fama e patrocínios, não muito diferente dos meios de dopagem convencionais, como substâncias anabolizantes. Todavia, quando se trata da modificação genética, esbarra-se na proteção ao patrimônio genético não modificado, no direito das futuras gerações e no risco de uma eugenia, como se abordou.

A dopagem genética fere o direito ao patrimônio genético não modificado, seja com a intervenção em célula somática ou germinativa, acarretando esta última à supressão da autonomia de futuros indivíduos com a violação do direito das futuras gerações, que ao nascerem teriam seus projetos de vida pré-estabelecidos, ou seja, seriam programados para serem atletas.

A criação de bebês a la carte com a intervenção em células germinativas, estaria, ademais, dando abertura para a escolha de atributos não só atléticos, mas também características como cor dos olhos, da pele, inteligência, altura e outros, pondo fim a loteria genética. Tudo isso resultaria na criação de uma forma de eugenia, ao segregar a espécie humana em transgênicos e os não-transgênicos, temendo-se uma relação de dominação daqueles sobre estes.

Por conseguinte, partindo-se do pressuposto de que o Estado Democrático de Direito deve comportar iguais liberdades fundamentais, prima face, não é possível compreender que o melhoramento genético seja uma prática lícita se aplicada ao esporte, pois poderá comprometer não somente o jogo limpo ou fair play, bem como o sadio desenvolvimento de uma sociedade, que possa num futuro próximo ser segregada entre atletas e pessoas geneticamente modificadas e os não modificados.

Portanto, em respeito aos princípios biojurídicos e bioéticos, ainda não é possivel permitir o doping genético, neste momento passível de se tornar um tipo de eugenia positiva, por objetivar o melhoramento humano e por em risco o futuro da humanidade.

Assim, cumpre-se ao objetivo deste trabalho em trazer reflexões sobre os desdobramentos desse método de dopagem, que requer um debate mais aberto, em que toda a sociedade e comunidade internacional possam discutir para além do esporte, sobretudo, quando em breve o Brasil será sede do maior evento esportivo do mundo, os Jogos Olímpicos. 


\section{Referências}

Artioli, G. G., Hirata, R. D.C. e Lancha Jr., A. H. (2007). Terapia gênica, doping genético e esporte: fundamentação e implicações para o futuro. Revista Brasileira de Medicina do Esporte, 13(5), 317-321. Recuperado em 2 março, 2016, de http://www.scielo. br/scielo.php?script=sci_arttext\&pi$\mathrm{d}=$ S1517-86922007000500013\&ln$\mathrm{g}=\mathrm{en} \& \mathrm{nrm}=\mathrm{iso}$

Andrade, R. J. de. (2003). Engenharia genética: dano genético e responsabilidade civil. En H. H. Barboza, J. Meirelles, J. e V. Barretto, de P. (Orgs.), Novos temas de biodireito e bioética (pp.181-218). Rio de Janeiro: Renovar.

Ascensão, J. de O. (2005). Intervenções no genoma humano: validade ético-jurídica. Em J. Ascensão de O. (Coord.), Estudos de direito da bioética (pp. 25-48). Coimbra: Almedina.

Barbas, S. (2005). Testes genéticos, terapia gênica, clonagem. Em J. Ascensão de O. (Coord.), Estudos de direito da bioética (pp. 309-328). Coimbra: Almedina.

Badenhausen, K. (2015, junho 10). The World's Highest-Paid Athletes 2015. Forbes, Recuperado em 9 março, 2016, de http://www.forbes.com/athletes/.

Bontempo, T. V. (2015). Melhoramento humano no esporte: o doping genético e suas implicações bioéticas e biojurídicas. Curitiba: Juruá.

Bomtempo, T. V. (2013). Resolução n. 1.805/2006 do Conselho Federal de Medicina: efetivação do direito de morrer com dignidade. Revista Sintese Direito de Família, 14(75), 204-221.
Bostrom, N. (2003). Human Genetic Enhancements: A Transhumanist Perspective. Journal of Value Inquiry, 37(4). Recuperado em 8 março, 2016, de http://www. nickbostrom.com/ethics/genetic.html

Brasil. Constituição (1988). Constituição da República Federativa do Brasil, de 05 de outubro de 1988. Brasília, DF. Recuperado em 3 março, 2016, de <http://www. planalto.gov.br/ccivil_03/Constituicao/ Constituicao.htm

Brasil. (2005). "Lein ${ }^{\circ} 11.105$ de 24 de março de 2005". Regulamenta os incisos II, IV e V do $\S 1^{\circ}$ do art. 225 da Constituição Federal, estabelece normas de segurançae mecanismos de fiscalização de atividades que envolvam organismos geneticamente modificados-ogm e seus derivados, cria o Conselho Nacional de Biossegurança - CNBS, reestrutura a Comissão Técnica Nacional de Biossegurança - CTNBIo, dispõe sobre a Política Nacional de Biossegurança - PNB, revoga a Lei no 8.974 , de 5 de janeiro de 1995, e a Medida Provisória n 2.191-9, de 23 de agosto de 2001 , e os arts. $5^{\circ}, 6^{\circ}, 7^{\circ}, 8^{\circ}, 9^{\circ}, 10$ e 16 da Lei no 10.814 , de 15 de dezembro de 2003, e dá outras providências. Brasília, DF. Recuperado em 10 março, 2016 de http://www.planalto.gov.br/ccivil_03/_ ato2004-2006/2005/lei/111105.htm

Cansino, E. G. de. (2007). Eugenia: avanço ou retrocesso? En C. M. R. Romeo Casabona e M. de F. Freira de Sá (Coord.). Desafios jurídicos da biotecnologia (pp. 265-306). Belo Horizonte: Mandamentos.

Carvalho, K. G. (2011). Direito constitucional: teoria do estado e da constituição: direito constitucional positivo (17a. ed.). Belo Horizonte: Del Rey. 
Casabona, C. M. R. (2002). Los genes y sus leyes: el derecho ante el genoma humano. Albolote: Comares.

Casabona, C. M. R. (2007). O desenvolvimento do direito diante das biotecnologias. En C. M. R. Casabona e M. de F. Freira de Sá (Coord.), Desafios jurídicos da biotecnologia (pp. 29-64). Belo Horizonte: Mandamentos.

Chamon Jr., L. A. (2010). Dignidade e diferença: há futuro para os direitos da personalidade? En C. Fiuza, M. de F. Freira de Sá e B. T. O. Naves (Coords.), Direito civil: atualidades IV: teoria e prática no direito privado (pp. 1-45). Belo Horizonte: Del Rey.

Coelho, M. M. (2012). Doping genético, o atleta superior e bioética. Revista Bioethikos. 6(2), 171-180. Recuperado em 13 março, 2016, de http://www.saocamilo-sp.br/pdf/bioethikos/94/a6.pdf.

Conselho da Europa. (1997). Convenção sobre os Direitos do Homem e a Biomedicina. Recuperado em 6 março, 2016, de http://www.gddc.pt/direitos-humanos/ textos-internacionais-dh/tidhregionais/ convbiologiaNOVO.html.

Conselho Federal de Medicina. (2009). Resolução n.1.931/2009. Recuperado em 9 março, 2016, de http://www. portalmedico.org.br/resolucoes/CFM/ 2009/1931_2009.htm.

Diedrich G. F. (2001). Genoma humano: direito internacional e legislação brasileira. En M. C. Cordero Leite dos (Ed.), Biodireito: ciência da vida, os novos desafios (pp. 214-232). São Paulo: Revista dos Tribunais.

Diniz, M. H. (2006). O estado atual do Biodireito (3ra. ed.). São Paulo: Saraiva.
Drumond. J. G. F. (2011). Tecnologia e esporte: perspectivas bioéticas. Revista Bioethikos. 5(4), 411-418. Recuperado em 3 março, 2016 de http://www.saocamilo-sp.br/pdf/bioethikos/89/A7.pdf

Fachin, L. E. (2004). Discriminação por motivos genéticos. En M. de F. Freira de Sá e Naves, B. T. O. (Orgs.), Bioética, Biodireito e o novo Código Civil de 2002. pp.179-198. Belo Horizonte: Del Rey.

Ferraz, J. B. S., Eler, J. P. e Rezende, F.M. (2012). Seleção genômica aplicada ao melhoramento animal: desafios atuais e expectativas futuras do criador. Anais do IX Simpósio Brasileiro de Melhoramento Animal, João Pessoa, Brasil. Recuperado em 13 março, 2016 de http:// sbmaonline.org.br/anais/ix/palestras/ pdf/Palestra08.pdf

Garcia, R. P. e Lemos, K. (2005). Temas (quase éticos) de desporto. Belo Horizonte: Casa da Educação Física.

Gomes, C. L. S. P. e Sordi, S. (2001). Aspectos atuais do projeto genoma humano. En M. de F. Freira de Sá (Ed.), Biodireito: ciência da vida, os novos desafios (pp. 169-195). São Paulo: Revista dos Tribunais.

Habermas, J. (2004). O futuro da natureza humana: a caminho de uma eugenia liberal? São Paulo: Martins Fontes.

Hammerchmidt, D. (2012). Identificación genética, discriminación y criminalidad: un análisis de la situación jurídico penal en España y en Brasil actualizada por la ley 12.654/2012. Curitiba: Juruá.

Jonas, H. (2006). O princípio responsabilidade: ensaio de uma ética para a civilização tecnológica. Rio de Janeiro: Contraponto, Puc-Rio. 
Junges, J. R. (1999). Bioética: perspectivas e desafios. São Leopoldo: unisinos.

Kant, I. (1993). Fundamentos da metafisica dos costumes. Río de Janeiro: Ediouro.

Linden, R. (2010). Terapia gênica: o queé, o que não é e o que será. Estudos Avançados, 24(70). (pp. 31-69). Recuperado em 6 março, 2016 de http://www.scielo.br/ pdf/ea/v24n70/en_a04v2470.pdf

Mello, L., e Bomtempo, T. V. (2013). Doping genético: nova forma de eugenia? En M. de F. Freira de Sá, D. L. Moureira e R. B. Almeida, de. (Orgs.). Direito Privado: Revisitações (pp. 149-169). Belo Horizonte: Arraes Editores.

Melo, H. P. de. (2011). O diagnóstico pré-natal e o eugenismo. En G. P. L. Ribeiro e A. C. B. Teixeira (Coord.), Bioética e direitos da pessoa humana (pp. 149196). Belo Horizonte: Del Rey.

Organização das Nações Unidas para a Educação, Ciência e Cultura (Unesco) (1997). Declaração sobre as Responsabilidades das Gerações Presentes em Relação às Gerações Futuras. Recuperado em 6 março, 2016 de http://unesdoc.unesco. org/images/0011/001108/110827por.pdf
Organização das Nações Unidas para a Educação, Ciência e Cultura (Unesco) (1997). Declaração Universal sobre o Genoma Humano e os Direitos Humanos. Recuperado em 6 março, 2016 de http://unesdoc.unesco.org/images/0012/001229/122990por.pdf

M. de F. Freira de Sá e Naves, B. T. O. (2011). Manual de biodireito (2a. ed.). Belo Horizonte: Del Rey.

Sarlet, I. W. (2001). Dignidade da pessoa humana e direitos fundamentais na Constituição Federal de 1988. Porto Alegre: Livraria do Advogado.

Sgreccia, E. (2002). Manual de bioética: volume 1: fundamentos e ética biomédica (2da. ed.). São Paulo: Loyola.

Silva, A. L. S. e Goellner, S. V. (2007). Universo biotecnológico e fronteiras partidas: esporte, gênero e novo eugenismo. Revista Gênero, 7(2), 79-89. Recuperado em 4 março, 2016 de http:// www.ieg.ufsc.br/admin/downloads/ artigos/08112009-024307silvagoellner.pdf

Westman, J. A. (2006). Genética médica. Río de Janeiro: Guanabara Koogan. 